\title{
Implementation of Competence Certification Test for the Improvement of Vocational School of Work Graduation Readiness
}

\author{
Latifahtur Rahmah ${ }^{1}$, Supari Muslim² \\ ${ }^{1}$ Student of Postgraduate State University of Surabaya \\ ${ }^{2}$ Postgraduate State University of Surabaya \\ latifahtur.17070895006@mhs.unesa.ac.id,supari.muslim@gmail.com
}

Keywords: Professional certification, work readiness, vocational school graduates

\begin{abstract}
:
With the enactment of the ASEAN Economic Community, it allows increased mobility and competition for labor freely among ASEAN member countries. This is a challenge for the Government of Indonesia to produce vocational graduates who are competent and highly competitive through Presidential Instruction No. 9 of 2016 concerning Revitalization of Vocational Schools. Based on the direction of the vocational education policy, several questions arise as follows: (1) what is meant by the competency certification test?; (2) what is the purpose of the competency certification test?; (3) what benefits will be obtained by carrying out the competency certification test?; and (4) what are the implications of the competency certification test on the work readiness of vocational graduates? This research is carried out through a literature review of the implementation of competency tests in several relevant vocational schools. Research concludes: (1) competency certification test is an assessment of individual performance, about how far the person concerned has been able to demonstrate knowledge and skills in their field; (2) the purpose of the competency certification test is to ensure students or vocational graduates can do work with industry-determined standards; (3) the benefits of competency certification are in recognition of the workforce in accordance with the required work competency standards; and (4) the implications of the certification test on work readiness of vocational graduates is that the level of work readiness of vocational graduates increases so that the opportunity to immediately get a job becomes higher.
\end{abstract}

\section{INTRODUCTION}

According to the National Education System Law Number 20 of 2003 concerning the purpose of national education article 3 and explanation of article 15, that Vocational High School is an education that prepares students primarily to work in certain fields. Vocational secondary schools prepare students to be productive human beings who can work according to their fields of expertise after going through the education process, including facing the labor market in the Asian Economic Community region.

With the implementation of the region and economic markets for the ASEAN Economic Community, it allows for increased mobility and competition for labor freely among fellow ASEAN member countries (Hendarman et al., 2016). asean economic community has various implications related to the development of human resources. Structural changes related to the asean economic community will cause an increase in the need for skilled workers and reduce the need for unskilled workers. This is a challenge for the Government of Indonesia to print vocational graduates who have high competency and competitiveness by their respective expertise programs.

Vocational education according to Billet (2011) is an education that prepares someone to prepare themselves and focus on: (1) preparation to enter the workforce; (2) career selection; (3) competency development owned; and (4) preparation of supplies and supporting experiences in the context of transitioning job positions from one position to another. The development of such competencies is carried out through the education process and certification testing at the competency certification institution. According to Sangay (2015), competency certification tests will ensure that vocational school graduates: (1) acquire the skills, desired knowledge and attitudes needed by industry and entrepreneurs; (2) can do work with specified standards. Therefore, a Competency Certification Agency is needed.

Gunawan (2006) explains that a good quality of vocational education is when the students who have undergone such education process can be accepted in the world of work fitted with the field of their expertise. Based on the aforementioned statement, it can be put forward that the vocational high schools as a producer of graduates should be able to make every individual student has the ability, skill, and expertise that are relevant to the demands and needs of the workforce. Thus, vocational education cannot be removed from the existing workforce development. The development of a marketable workforce should be made by vocational education based on the needs of the world industry through an increase in competence of graduates.

According to the Director of Course and Institutional Development (2010), the Competency Certification Institution is an institution whose task is to improve the skills of individuals and community groups in Indonesia. By forming several 
Vocational education is education that prepares a person to focus on: (1) preparation for work, (2) one's career choice, (3) developing one's competency, and (4) as a provision from experience that supports the transition of job positions from one position to another. Furthermore, Rivai \& Murni (2010: 91) explains that vocational secondary education is an education in secondary education that prioritizes the development of the ability of students to carry out certain types of work. Vocational education is also often associated with life-long understanding learning. This is related to the efforts made by individuals to continue to develop the skills and knowledge of their work to continue to survive in the face of social and economic changes today (Clarke and Winch, 2007). Vocational education must be able to make student individuals in it find the ability and pleasure in doing work so that in their work they will find opportunities to develop themselves, their thoughts, and their skills to help them survive and at the same time enjoy the life they live.

\subsection{Competency Certification Test}

According to Wenrich (1974), all competency that can be developed includes all domains belonging to learners, namely knowledge, skills, and work attitudes, while learners' potentials include feeling, sight, thought and action. Therefore, vocational education is directly related to the way of empowering all potentials belonging to learners in order that they possess certain competency.

Vocational competency construct according to Akhyar (2009): (1) The vocational competency construct consists of six indicators, namely work principle knowledge, work procedure knowledge, lathe practice skill, milling practice skill, work accuracy, and work consistency; (2) The learning style construct consists of two indicators, namely creativity development and innovative experience; (3) The personality construct consists of six indicators, namely achievement motivation, responsiveness, adaptiveness, progressiveness, enthusiasm, and self-confidence; (4) There a positive and significant reciprocal relationship between student's learning style and their personality, there a positive and significant relationship between students' learning style and their vocational competency; there a negative and significant relationship between students' personality and their vocational competency; (5) The model of vocational competency assessment as the main research finding is called the PLC model consisting of 3 components, namely personality (P), learning style (L), and competency (C). The personality consists of six factors, namely achievement motivation, responsiveness, adaptiveness, progressiveness, enthusiasm, and selfconfidence. The learning style is an implementation 
of a learning model oriented to practice (work-based learning), namely lathe and milling practices. The learning style consists of two indicators, namely skill development and innovative experience. The competency consists of six indicators, namely work principle knowledge, work procedure knowledge, lathe practice skill, milling practice skill, work accuracy, and work consistency

Sutrisno (2006) Describing education and training is one or perhaps the only way to prepare a competent workforce to achieve comparative and competitive advantages. This was confirmed by Pavlova (2009) that competency-based training was chosen by most governments in Western society as a model of vocational education (VE). To prepare the middle-level workforce, the role of vocational secondary education is very strategic and significant.

Substantially, Garavan \& McGuire (2001) explain competencies that can be seen from two aspects, namely individual attributes and learning outcomes. Whereas competence according to Wahba (2016) is defined as the ability of individuals to use, apply and demonstrate related knowledge, skills and attitudes to perform tasks well and that can be measured against standards that are required at work and assessed based on the evidence available at the work site. These competencies affect the responsibilities and performance of individual jobs in work and are usually divided into two categories, namely knowledge, and skills. It can be concluded that competency testing is an individual assessment in demonstrating knowledge and skills in their field. The Director of Course and Institutional Development (2010) explained that the Competency Certification Institution is one way to improve the skills of individuals and community groups in Indonesia. By creating Competency Certification Institutions distributed in the regions, it can eliminate skill gaps between urban communities and village communities.

In various industrial sectors and vocational, central and school institutions, attention is paid to the performance of craftsmen /apprentices/trainees/ students by implementing CBET Competency Based Training and Education and CAMS Quality Assurance Management System. The purpose of this system is to provide guidance to management to establish valid and reliable controls in places with the intention of having sufficient confidence to fulfill their business objectives by ensuring that their employees/apprentices/trainees/students are well trained, assessed, verified and proven competent at the work site and they can release their responsibilities safely and effectively. The TVET Competency certification strategy based on "work competency" is set for each career field in each type of department. Competency-based TVET systems generally use a combination of strong techniques to ensure that the needs of various industrial sectors are handled (demand), competency-based training courses or programs are developed, competencybased assessment /verification is carried out, employees/ interns/trainees/students are trained efficiently and competently. In this case, techniques such as the MIS Management Information System, Knowledge Management KM, M \& E Monitoring \& Evaluation and Competency Guarantee Management System, also known as the Competency Assurance Management System CAMS are generally used Wahba (2016).

Furthermore, Sitalonga (2015) explained that the recognition of work competencies was carried out through work competency certification in this case by the National Professional Certification Body as an independent body. After that, National Professional Certification Agency was formed based on Government Regulation No.23 of 2004. Article 2 paragraph (2) and paragraph (3) states that national professional certification agency is an independent institution in carrying out professional certification and is responsible to the President. The technical implementation of competency certification in Article 4 paragraph (1) states that national professional certification agency can grant licenses to Professional Certification Institutions that meet the requirements set by national professional certification agency (paragraph (2)). national professional certification agency does not conduct training but conducts competency tests based on indonesian national work competency standards that already exists in every industrial sector. Indonesian national work competency standards are a standard product that is produced by industry through agreements and conventions which are then ratified by the Minister of Manpower and Transmigration (PP. No. 23 of 2004). Furthermore, in national professional certification agency Guidelines No. 201-2005 explained how a Professional Certification Institutions forms an organization that has international standards referring to ISO 17024. Professional Certification Institutions does not conduct training, but tests competence in a workplace called the Competency Test Place

\subsection{Purpose of Competency Certification Test}

Hapsari (2016) describes that starting in 2014 the Ministry of Tourism requires tourism workers to take competency tests. This is by the rules set out in Law Number 10 of 2009 concerning Tourism. Competency certification policy is an obligation that must be followed by all tourism workers in the face of national and international labor competition. With the competency certification, tourism workers are expected to get a salary that is by their competency standards. Furthermore, to equip vocational high schools' graduates with competency certificates that are recognized by the business world/industry so 
that these vocational high schools' graduates have high competitiveness, then since 2015 Dit. The development of Vocational Schools, Ministry of Education and Culture with the National Professional Certification Agency has carried out the development activities of Vocational Schools into the First Party Certification Institution (PCI-P1) which is implemented in the vocational high schools called vocational competency tests.

Sangay (2015) explains that competency certification testing will ensure that students or vocational graduates can do work with specified standards; and that they possess and acquire the skills, desired knowledge, and attitudes needed by industry and entrepreneurs. The purpose of the professional certification to recruit Top LSP (2016) is to ensure and maintain the competencies that have been obtained through the learning process both formal, non-formal, job training, or work experience. Because in the world of work competency must be maintained, not only having been competent, but competent and continuously competent. Competency-Based Assessment involves gathering evidence to prove that a person can do the elements of competence and performance criteria as stated in the National Competency Standards. In traditional assessment, one takes a single assessment or examination. In competencybased assessments, there are several activities to determine whether someone has demonstrated competence. An individual can be assessed during their training, at the end of their training, or even not do formal training.

\subsection{Benefits of Competency Certification Test}

Anane (2013) described Competency Based Education and Training as an industry and demand driven (outcomes-based) education and training programmed based on well-defined industry generated standards (occupational standards). Anane further stated that these industry standards are the basis upon which the program (curriculum), assessment and learning materials are designed and developed. CBET programs focus on what the participant is expected to be able to do in the workplace as opposed to just having theoretical knowledge. It is therefore a training programmed which ensures that learners gain the necessary knowledge, skills and attitudes or values to be successful in the working environment.

Regarding the Ministry of Education and Culture (2016), it concerns the National Professional Certification Agency and PP 31 of 2006 concerning the issuance of Labor Law Number 13 of 2003. The National Job Training System is increasing. This has a positive impact through the Professional Certification Institutions (PCI) supported by
Industry Associations, Professional Associations, Professional Training Institutions and people in the field. On increasing power competitiveness and labor productivity.

According to Wahba (2016) Job competency certification acknowledgment of workers who have knowledge, skills and work attitudes by required work competency standards, thus competency certification ensures that the workforce is certified as credibility in doing a job that is his duty and responsibility.

\subsection{Implementation of Competency CertificationTest}

According to Boud \& Solomon (2001), competency refers to an ability to demonstrate what one has acquired before. Competency attainment depends not only on the effective implementation of a learning model, but also on the assessment system. Through an integrated assessment system, schools obtain accurate information on the learning quality so that they can make up for the weaknesses. Thus, assessment plays an important role in controlling the quality of education. Assessment is supposed to reflect understanding of integrated learning. Assessment of vocational competency can be accurately carried out if it includes knowledge, skill, and work attitude aspects. Besides, assessment can also be viewed from a variety of determinant factors directly related to competency attainment, such as a learning model and student's personality characteristics. Thus, a comprehensive description of students' quality can be obtained.

Research Results Samsudi, Budiyono, Supraptono, Wijaya, and Widayat (2007) found that implementation of competency tests for students showed that: 1) $50.33 \%$ of schools collaborated with industrial world; 2) $26.04 \%$ of schools collaborate with professional associations; 3) $18.72 \%$ of UKK are held by schools entirely; 4) $17.33 \%$ of schools collaborate with Professional Certification Institutions, and 5) $1.84 \%$ of schools implement with other models. From this percentage, it can be seen that only $17.33 \%$ of students collaborate with Professional Certification Institutions. It can be concluded that only $17.33 \%$ of schools whose students get competency certificates.

The Director of Vocational Development gives the school the freedom to choose one of the five choices. The provision of freedom is based on the consideration that in Indonesia the conditions of vocational schools are very diverse, especially practice equipment facilities, teacher qualifications, industrial world support capacity around the school, and economic abilities of parents of students. These studies indicate that the most widely applied by international schools is the collaboration competency test with industrial world. The model of the school competency test with industrial world, the 
assessors, came from the school and industrial world, and the certificate was issued by industrial world.

Setiawan (2017) explained that the Presidential Instruction No.9 of 2016 concerning Revitalization of Vocational Schools, national professional certification agency had the task to (1) Speed up competency certification for vocational high school graduates; (2) Speed up competency certification for students and vocational education staff; (3) Accelerating administration license for Vocational School as a first-party Professional Certification Institution.

Setiawan (2017) explained that to carry out the duties of the national professional certification agency has compiled a National Action Plan for Certification for Vocational Students, which is intended to be implemented for 2016 students. To be a reference for all relevant parties, then the implementation of the guidelines for 4 (four) choices for certification for vocational graduates: (1) The pattern of certification implementation by Professional Certification Institutions P-1 Vocational School is only for students from Vocational Schools concerned and vocational students who are designated as networking (P1) P1 Professional Certification Institutions is a competent company that is determined by the Directorate of Vocational Education and/or Provincial Education Service; (2) The Implementation Pattern of Certification by Professional Certification Institutions P2 is only for students from Vocational Schools who do not have Professional Certification Institutions P1 and within the scope of a particular region; (3) The pattern of implementation of certification by Professional Certification Institutions P3 is only for students from Vocational P3 but not yet have PCI P1 and PCI P2 in certain regions.

\subsection{The National University of Indonesia and the Provincial Education Service and the Directorate of Vocational Development}

The revitalization of vocational education (2016) as for the scope of development activities of Vocational School to become PCI-P1 consists of: (1) facilitation of preparation and training of competency assessors; (2) preparation of Competency Test Place; (3) preparation of competency test material; (4) training in preparation and quality documents.

Revitalization of vocational education (2016) also explains that later every prospective vocational high schools graduate will take the competency certification test carried out at PCI-P1 in their respective schools or at the nearest vocational high schools PCI-P1. If you pass the competency test, participants will get a certificate as proof of recognition of their competencies. The formation of PCI-P1 is carried out with the following strategies: (1) Approach area, namely if in an area there are several Vocational Schools that do not have PCIP1, one PCI-P1 will be developed which can be utilized by all vocational high schools $s$ in the region; (2) The formation of PCI-P1 is focused on schools that have students> 600: currently there are around 4,000 vocational high schools with students> 600 , with a total number of students totaling $90 \%$ of the total number of vocational high schools students throughout Indonesia.

\section{RESULT AND DISCUSSION}

According to Vocational Revitalization (2016), the ASEAN Economic Community allows increased mobility and competition for labor freely among all ASEAN member countries. Asian economic community has various implications related to the development of human resources. Structural changes related to the Asian economic community will cause an increase in the need for skilled workers according to industry needs and reduce the need for unskilled workers. This is a challenge for Indonesia to produce vocational graduates who have highcompetency competencies in their fields by collaborating with the world of industry. One effort has been made to minimize the work competency gap of vocational education graduates with the needs of the business world or the industrial world, among others through the preparation of certification schemes for vocational education graduates by involving professional associations and industrial world in implementing competency certification tests.

Whereas according to Wahba (2016) the competencies possessed by individuals are to use, implement and demonstrate knowledge, skill, and attitudes assessed based on the evidence available at the work site. These competencies affect the responsibilities and performance of individual jobs in work and are usually divided into two categories, namely knowledge, and skills. To conduct competency assessments according to Wahba's opinion, mature research is needed and of course extra funds.

According to the revitalization of vocational education (2016), the Expertise Competency Test (UKK) can be replaced with a competency test carried out by PCI-P1, in this case, the certification fee will be subsidized by the government through the School Operational Assistance (BOS) fund. The vocational high schools Directorate plans to establish 1,650 Vocational Schools that will act as PCI-P1 until 2019. This is done to minimize the work competency gap of vocational education graduates with the needs of the business / industrial 
world, among others through the preparation of certification schemes for vocational education graduates by involving professional associations and industrial world as well in the implementation of the competency test.

The following is the improvement plan of competency test places, assessor dan assessor master by the Directorate of Course and Training Development (2016) in revitalizing vocational high schools as shown in Table 1 below.

Table1: Planning for Upgrading Competency Test Places, Assessor dan Assessor Master.

\begin{tabular}{|c|c|c|c|c|c|}
\hline Year & 2015 & 2016 & 2017 & 2018 & 2019 \\
\hline $\begin{array}{l}\text { Place of } \\
\text { competen } \\
\text { cy test }\end{array}$ & $\begin{array}{l}50 \\
\text { place }\end{array}$ & $\begin{array}{l}160 \\
\text { place }\end{array}$ & $\begin{array}{l}100 \\
\text { place }\end{array}$ & $\begin{array}{l}500 \\
\text { place }\end{array}$ & $\begin{array}{l}600 \\
\text { place }\end{array}$ \\
\hline $\begin{array}{l}\text { Assessor } \\
\text { and } \\
\text { Assessor } \\
\text { Master }\end{array}$ & $\begin{array}{l}100 \\
\text { people }\end{array}$ & $\begin{array}{l}100 \\
\text { people }\end{array}$ & $\begin{array}{l}140 \\
\text { people }\end{array}$ & $\begin{array}{l}700 \\
\text { people }\end{array}$ & $\begin{array}{l}700 \\
\text { people }\end{array}$ \\
\hline $\begin{array}{l}\text { Assistance } \\
\text { for } \\
\text { competent } \\
\text { certified } \\
\text { students }\end{array}$ & $\begin{array}{l}51.73 \\
3 \\
\text { people }\end{array}$ & $\begin{array}{l}65.04 \\
0 \\
\text { people }\end{array}$ & $\begin{array}{l}25.00 \\
0 \\
\text { people }\end{array}$ & $\begin{array}{l}25.00 \\
0 \\
\text { people }\end{array}$ & $\begin{array}{l}25.00 \\
0 \\
\text { people }\end{array}$ \\
\hline
\end{tabular}

From the school operational assistance, the Directorate of Course and Training Development hopes that the competency test place improvement plan, testers, and master testers can be carried out. Mulder et al. (2006) explain the weaknesses of Competency Tests that hinder the readiness of vocational graduates to work in several schools: (1) Emphasis on unequal competency assessment; (2) Assessment of competence frustrates learning and development more than just supporting it; (3) Difficult to determine whether a competency is achieved or not, competency development takes a long time, and some competencies are only applied after graduation, which makes it difficult to assess them during the training program; (4) Competencies are formulated in too general terms, which means that they do not have discriminatory power in assessment, people's performance is often assessed in the context of a simulation professional who does not guarantee that the same person will be competent in the actual professional context as well; (5) Competency profile analysts do not always have adequate ability and credibility in assessing competent people. It is illustrated that although in all countries, competency is demanded and more or less integrated into the system, measurements taken by the government, economy, and institutions face strong criticism. These criticisms may have beneficial effects on other countries because they can learn from experience. From Mulder's explanation above, to prepare vocational high schools graduates who are ready to work, competency testing must be planned, analyzed until thoroughly evaluated until the root of this aim is to improve work readiness of vocational graduates. Research Riskiyah (2018) explains that evaluations that need to be calculated in carrying out competency certification tests for senior high school culinary expertise programs through professional certification institutions ( PCI) are: (1) Context, the need for institutional development for Professional Certification Institutions to add insight in formulating goals and objectives with strong involvement from industrial world; (2) Input, there need to be better improvements for the implementers of Professional Certification Institutions and students; (3) Process, arrangement of training schedules and implementation are really well designed and the assessment must be in accordance with the standards of national professional certification agency; (4) Product, it is necessary to increase and improve the implementation by improving and increasing the components that are still low and moderate, so that in the future the program can run better.

Some researchers examined the effect of implementing professional certification tests on the work readiness of vocational high schools' graduates. The first is the implementation implication of professional certification for senior high school graduates in Indonesia. According to the research conducted by Riya (2013) that there is a positive effect of work competence on the work readiness of class XII students of the Electrical Engineering Installation Program at vocational high schools SMKN 2 Yogyakarta. Agree to hear from Syaiful (2017) that there is a positive influence on the competency test on the work readiness of students in the State Vocational Competency in Light Vehicle Engineering Expertise in Malang City.

From the above research, it can be concluded that the importance of professional certification at school and it would be better if the certification was carried out in collaboration with Professional Certification Institutions so that each student has a professional certification that is licensed by the National Professional Certification Agency.

\section{CONCLUSIONS}

Based on a study of various literature and relevant research results as described above, it can be concluded that:

1. Competency Certification Test is one way to improve the skills of vocational students as individuals and community groups in 
Indonesia by conducting individual assessments in demonstrating knowledge and skills in their fields.

2. The purpose of the competency certification test is to ensure that students or vocational graduates can do work with specified standards; and that vocational students have and acquire the skills, desired knowledge, and attitudes needed by industry and entrepreneurs.

3. The benefits of work competency certification are recognition of workers who have knowledge, skills and work attitudes by the required work competency standards. Thus, competency certification ensures that the workforce (certificate holder) is guaranteed credibility in carrying out work that becomes his duty and responsibility.

4. The competency certification test greatly influences the readiness of work of graduates because by doing competency skills students become more skilled and confident in facing the world of work. From the study above, it can be seen that only $17.33 \%$ of students collaborate with Professional Certification Institutions. It can be concluded that only $17.33 \%$ of schools have students who have a professional certification that is licensed by the National Professional Certification Agency. In this case, revitalization needs to be held in the procurement of Competency Certification Tests so that more schools will cooperate with Professional Certification Institutions.

\section{REFERENCES}

Anane. (2013). Competency based training: Quality delivery for technical and vocational education and training (TVET) institutions. Educational Research International, 2(2), 117- 127.

Akhyar. (2009). A Model of Vocational Competency Assessment of Industrial Engineering Students of Vocational High Schools. Yogyakarta: UNY PRESS.

Billett, Stehen. (2011). Vocational Education (Purposes, Trsditions and Prospects). Griffith University, QLD, Australia: Springer.

Boud, D., \& Solomon, N. (2001). Work-based learning: a new higher education? Ballmoor, Buckingham: SRHE and Open University Press.

Clarke, Linda and Winch, Christopher. (2007). Vocational Education (International approaches, developments and systems). New York: Routledge.

Director of Course and Institutional Development. (2010). Social Assistance Increasing the Capacity of Competency Certification Bodies. Jakarta.

Garavan, T. N., \& McGuire, D. (2001). Competencies and work-place learning: some reflections on the retoric and the reality. Journal of work-place learning, 13(4), 144-154.
Hendarman, et al. (2016). Revitalization of Vocational Education. Jakarta: Ministry of Education and Culture.

Mulder, M., T. Weigel \& K. Collins (2006). The concept of competence concept in the development of vocational education and training in selected EU member states. A critical analysis. Journal of Vocational Education and Training, 59, 1, 65-85.

Okwelle, P. C. (2008). Employers' perceptions of the role of technical and vocational education (tve) in sustainable development in Nigeria. Uniswa Research Journal, 23, 57 - 66.

Riya. (2013). Pengaruh Kompetensi Kerja Dan Motivasi Kerja Terhadap Kesiapan Kerja Siswa Kelas XII Program Studi Teknik Instalasi Tenaga Listrik SMKN 2 Yogyakarta. Yogyakarta. Yogyakarta: Universitas Negeri Yogyakarta.

Sitalonga. (2015). Perbandingan Penerapan Sistem Sertifikasi Kompetensi di Indonesia dan Di NegaraNegara Lain. Jakarta: STEIN.

Samsudi, Budiyono, A., Supraptono, E., Wijaya, B.R., \& Widayat, W. (2007). Pelaksanaan Uji Kompetensi Keahlian Dalam Rangka Ujian Nasional SMK Laporan Penelitian. Kerjasama Universitas Negeri Semarang dengan Direktorat Pembinaan SMK. Ministry of Education.

Setiawan. (2017). Pedoman Pelaksanaan Sertifikasi Kompetensi Bagi Lulusan SMK. Jakarta: Ministry of Education and Culture.

Rivai, Veithzal \& Murni, Sylviana. (2010). Education Management Analisis Teori dan Praktik. Jakarta: Rajawali Pers.

Sangay. (2015). Regulations for National Assessment \& Certification System for Tvet In Bhutan. India: Department of Occupational Standards Ministry of Labour \& Human Resources Royal Government of Education Management Analisis Teori dan Praktik. Bhutan.

Syaiful. (2017). Pengaruh Hasil Uji Kompetensi Keahlian, Pengalaman Praktik Kerja Industri, Aspirasi Karir dan Motivasi Kerja Terhadap Kesiapan Kerja Siswa SMK Negeri Kompetensi Keahlian Teknik Kendaraan Ringan di Kota Malang. Malang: Universitas Malang.

Laws of the republic Indonesia PP No. 32/2013. About National Education Standards.

Wahba. (2016). Competence Standards for Technical and Vocational Education and Training TVET. India: UNESCO.

Muslim. Et al. (2018). Critrical Review Pada FaktorFaktor Yang Berpengaruh Terhadap Kesiapan Kerja Siswa Sekolah Menengah Kejuruan (SMK). Surabaya: Universitas Negeri Surabaya.

Hapsari. (2016). Study of Course and Training Programs Related to Types of Skills, Certification and Placement of Graduates. Semanrang: Journal UNNES.

Rizkiyah. (2018). Pelaksanaan Uji Sertifikasi Kompetensi Siswa SMK Program Keahlian Tata Boga Melalui 
Lembaga Sertifikasi Profesi (LSP)P1 Dengan Model Evaluasi CIPP di SMK N 3 Malang. THESIS Postgraduate Program in Universitas Negeri Malang.

Gunawan, R. (2006). [The relevance of VHS graduates with workforce demand]. Bandung: UPI

Wenrich, R. C. (1974). Leadership in administration of vocational education. Columbus, Ohio: Charles E. Merrill Pub. Co. 